\title{
Kemampuan Penalaran Matematis dalam Menyelesaikan Soal Literasi Matematika Ditinjau dari Gaya Kognitif
}

\author{
Mellania Nur 'Aisyah ${ }^{1}$, Sutrisno $^{2 *}$, \& Agnita Siska Pramasdyahsari ${ }^{3}$ \\ 1, 2, 3 Universitas PGRI Semarang, Semarang, Indonesia
}

\section{INFO ARTICLES}

\section{Article History:}

Received: 09-10-2021

Revised: 30-12-2021

Approved: 30-12-2021

Publish Online: 31-12-2021

\section{Key Words:}

Mathematical Reasoning Abilities; Field Independent; Field Dependent; Cognitive Styles;

\begin{abstract}
This study aims to describe how students' mathematical reasoning abilities in solving problems based on mathematical literacy in terms of field independent and field dependent cognitive styles. Based on these objectives, this research is a descriptive qualitative research. The data collection technique used is GEFT, reasoning ability tests, interviews, and is equipped with documentation. The data analysis techniques used are data reduction, data display, and conclusion drawing/verification. The indicators used in this study are presenting mathematical statements orally and in writing, submitting conjectures, performing mathematical manipulations, providing reasons or evidence for several solutions, drawing conclusions, and checking the validity of arguments. The results in this study indicate that the field independent cognitive style students have six indicators while the field dependent cognitive style students are only able to master two indicators, namely presenting mathematical statements orally and in writing, making assumptions and performing mathematical manipulations.
\end{abstract}

\begin{abstract}
Abstrak: Penelitian ini bertujuan untuk mendeskripsikan bagaimana kemampuan penalaran matematis siswa dalam menyelesaikan soal berbasis literasi matematika ditinjau dari gaya kognitif field independent dan field dependent. Berdasarkan tujuan tersebut penelitian ini termasuk penelitian kualitatif deskriptif. Teknik pengumpulan data yang digunakan yaitu GEFT, tes kemampuan penalaran, wawancara, serta dilengkapi dengan dokumentasi. Teknik analisis data yang digunakan yaitu data reduction, data display, dan conclusion darwing/verification. Indikator yang digunakan dalam penelitian ini yaitu menyajikan pernyataan matematika secara lisan dan tertulis, mengajukan dugaan, melakukan manipulasi matematika, memberikan alasan atau bukti terhadap beberapa solusi, menarik kesimpulan, dan memeriksa keshahihanargumen. Hasil dalam penelitian ini menunjukkan bahwa siswa bergaya kognitif field independent memiliki keenam indikator sedangkan siswa bergaya kognitif field dependent hanya mampu menguasai dua indikator yaitu menyajikan pernyataan matematika secara lisan dan tertulis, mengajukan dugaan dan melakukan manipulasi matematika.
\end{abstract}

Correspondence Address: J1. Sidodadi Timur No. 24, Semarang, Jawa Tengah, Indonesia, Kode Pos 50232; e-mail: sutrisnojr@upgris.ac.id

How to Cite (APA 6 $^{\text {th }}$ Style): 'Aisyah, M.N., Sutrisno, S., \& Pramasdyahsari, A.S. (2021). Kemampuan Penalaran Matematis dalam Menyelesaikan Soal Literasi Matematika Ditinjau dari Gaya Kognitif. JKPM (Jurnal Kajian Pendidikan Matematika), 7(1): 143-158. http://dx.doi.org/10.30998/jkpm.v7i1.11127

Copyright: 2021 Mellania Nur ‘Aisyah, Sutrisno Sutrisno, Agnita Siska Pramasdyahsari

Competing Interests Disclosures: The authors declare that they have no significant competing financial, professional or personal interests that might have influenced the performance or presentation of the work described in this manuscript. 


\section{PENDAHULUAN}

Matematika merupakan mata pelajaran yang diajarkan pada setiap jenjang pendidikan dari mulai SD, SMP, SMA, sampai perguruan tinggi. Metamatika menjadi suatu keperluan bagi bekal hidup manusia, hal itu dilihat dari aktivitas manusia yang tidak terlepas dari matematika, misalnya dalam kegiatan mengukur besaran, membilang benda, jual-beli, dan lain sebagainya (Isrokatun, et. $a l ., 2020)$. Tidak sedikit orang-orang beranggapan bahwa matematika itu sulit dan yang terbayang adalah matematika itu berisi tentang konsep, bilangan, rumus, dan simbol. Namun hal tersebut tidak sepenuhnya salah karena matematika memanglah ilmu yang mempelajari tentang logika, besaran, susunan, dan konsep-konsep yang saling berkaitan yang di dalamnya memang terdapat bilangan, rumus, dan symbol (Mulyatna, et. al., 2020).

Adapun tujuan umum pembelajaran matematika untuk semua jenjang, yaitu: (1) memahami konsep matematika, menjelaskan ketertkaitan antarkonsep dan mengaplikasikan konsep atau algoritma, secara luwes, akurat, efisien, dan tepat, dalam pemecahan masalah; (2) menggunakan penalaran pada pola dan sifat, melakukan manipulasi matematika dalam membuat generalisasi, menyusun bukti, atau menjelaskan gagasan dan pernyataan matematika; (3) memecahkan masalah yang meliputi kemmapuan memahami masalah, merancang model matematika, menyelesaikan model dan menafsirkan solusi yang diperoleh; (4) mengomunikasikan gagasan dengan simbol, tabel, diagram, atau media lain untuk memperjelas keadaan atau masalah; serta (5) memiliki sikap menghargai kegunaan matematika dalam kehidupan, yaitu memiliki rasa ingin tahu, perhatian, dan minat dalam mempelajari matematika, serta sikap ulet dan percaya diri dalam pemecahan masalah (Depdiknas, 2006). Sementara itu, Nasional Council of Teacher of Mathematics (NCTM) menetapkan lima standar kemampuan matematis yang dimiliki siswa, yaitu kemampuan pemecahan masalah (problem solving), kemampuan komunikasi (communication), kemampuan koneksi (connection), kemampuan penalaran (reasoning), dan kemampuan representasi (representation) (NCTM, 2000). Berdasarkan Permendiknas dan NCTM tersebut, maka salah satu yang menjadi fokus utama tujuan pembelajaran matematika adalah kemampuan penalaran matematis.

Kemampuan penalaran matematis adalah kemampuan berpikir dalam melihat dan menganalisis fenomena yang muncul untuk kemudian disusun suatu konjektur yang bisa digunakan dalam penarikan kesimpulan (Offirstson, 2012). Kemampuan penalaran sangat berperan penting dalam mencapai hasil belajar matematika yang baik. Kemampuan penalaran sangat dibutuhkan oleh siswa dalam belajar matematika, karena pola berpikir yang dikembangkan dalam matematika sangat membutuhkan dan melibatkan pemikiran kritis, sistematis, logis, kreatif dalam menarik kesimpulan dari beberapa data yang mereka dapatkan (Setyaningrum, et. al., 2017). Materi matematika dan penalaran merupakan dua hal yang tidak dapat dipisahkan, yaitu materi matematika dipahami melalui penalaran dan penalaran dipahami dan dilatihkan melalui belajar matematika (Depdiknas, 2006). Sehingga dalam mempelajari mata pelajaran matematika, penalaran matematis sangat dibutuhkan dikarenakan keduanya saling berhubungan. Adapun indikator penalaran matematis yaitu menyajikan pernyataan matematika secara lisan dan tertulis, mengajukan dugaan, melakukan manipulasi matematika, memberikan alasan atau bukti terhadap beberapa solusi, menarik kesimpulan dan memeriksa keshahihan argumen.

Kemampuan bernalar tidak hanya dibutuhkan siswa ketika mereka belajar maupun mata pelajaran lainnya, namun sangat dibutuhkan setiap manusia di saat memecahkan masalah ataupun di saat menentukan keputusan (Shadiq, 2014). Adapun seorang siswa dilatih untuk menyelesaikan masalah, maka siswa itu akan mampu mengambil keputusan sebab siswa itu menjadi mempunyai keterampilan tentang bagaimana mengumpulkan informasi yang relevan, menganalisis informasi dan menyadari betapa perlunya meneliti kembali hasil yang telah diperolehnya (Hudojo, 2005). Namun tingkat kemampuan bernalar siswa masih dinilai rendah karena kurangnya pemahaman konsep dan belum begitu menguasai literasi matematika. 
Literasi matematika adalah kemampuan individu untuk merumuskan, mempekerjakan, dan menafsirkan matematika dalam berbagai konteks, termasuk kemampuan untuk melakukan penalaran matematika dan menggunakan konsep, prosedur, dan fakta untuk menggambarkan, menjelaskan, atau memprediksi fenomena (Somakim, et. al., 2016). Literasi matematika merupakan kemampuan seseorang untuk merumuskan, menggunakan dan menafsirkan matematika dalam berbagai konteks masalah kehidupan sehari-hari secara efisien (Sari, 2015). Kemampuan literasi matematika membantu seseorang untuk memahami peran atau kegunaan matematika di dalam kehidupan seharihari dan sekaligus menggunakannya untuk membuat keputusan-keputusan yang tepat atas berbagai permasalahan atau fenomena yang terjadi (Khanifah, et. al., 2019; Asmara, et. al., 2017).

Dalam kenyataannya, kemampuan literasi matematika siswa di Indonesia belum memuaskan dan sangat tertinggal. Pernyataan tersebut mengacu pada data hasil tes kemampuan literasi matematika dalam PISA yang diselenggarakan secara internasional dibawah naungan Organisation for Economic Cooperation and Development (OECD) yang bertujuan untuk mengukur tingkat kemampuan literasi siswa berumur sekitar 15 tahun. Hasil studi Program for International Student Assesment (PISA) 2018 yang dirilis oleh OECD menunjukkan bahwa Indonesia berada di peringkat 72 dari 78 negara dengan skor matematika yakni 379 (OECD, 2019). Berdasarkan studi Trends in Mathematics and Science Study (TIMSS) 2015 menunjukan prestasi siswa dalam bidang matematika mendapat peringkat 46 dari 51 negara dengan skor 397.

Berbagai rancangan kegiatan dan pembelajaran sangat diharapkan dapat memfasilitasi siswa untuk memperoleh pengetahuan dan keterampilan sebagai upaya meningkatkan kemampuan penalaran matematis dan kemampuan literasi matematika siswa. Dalam proses tersebut seringkali diasumsikan bahwa siswa memilik gaya kognitif yang sama padahal masing-masing siswa memiliki gaya kognitif yang berbeda-beda (Sutrisno, et. al., 2013). Dengan gaya kognitif yang berbeda-beda dari masing-masing siswa dapat mempengaruhi kemampuan siswa dalam berpikir dan bernalar. Hal tersebut sesuai dengan pernyataan dari Coop dan Sigel bahwa gaya kognitif mempunyai korelasi dengan perilaku intelektual dan perseptual (Lastiningsih, 2014). Intelektual terkait dengan kemampuan seseorang dalam berpikir, sedangkan perseptual terkait dengan kemampuan seseorang dalam memandang atau menafsirkan sesuatu. Gaya kognitif seseorang dapat menjelaskan perbedaan keberhasilan individu dalam belajar (Sari, et. al., 2019).

Salah satu jenis-jenis gaya kognitif yaitu gaya kognitif field independent dan field dependent. Gaya kognitif dapat dibedakan berdasarkan perbedaan psikologis yaitu kognitif field independent (FI) dan field dependent (FD) (Hidayat, et. al., 2013). Orang FD melihat isyarat lingkungan sebagai petunjuk dalam merespon suatu stimulus dan memandang informasi secara umum. Orang FD dikategorikan sebagai seorang yang berpikir secara global, berperilaku sensitif secara sosial dan berorientasi interpersonal, lebih suka bekerja kelompok dalam mengerjakan tugasnya. Sedangkan orang FI cenderung kurang tertarik dengan fenomena sosial dan lebih suka dengan ide-ide dan prinsip-prinsip yang abstrak, kurang hangat dalam hubungan interpersonal, dalam mengerjakan tugasnya merasa efisien bekerja sendiri.

Berbagai jenis penelitian tentang kemampuan penalaran matematis siswa telah dilakukan (Agustin, 2016; Muslimin \& Sunardi, 2019; Raharjo, et. al., 2020). Namun masih sedikit penelitian akan hal tersebut yang dikaitkan dengan literasi matematika. Oleh karena itu, perlu dilakukan penelitian untuk mendeskripsikan kemampuan penalaran matematis siswa dalam literasi matematika ditinjau dari gaya kognitif field independent dan field dependent. Melalui deskripsi ini, diharapkan dapat dijadikan referensi bagi pendidik dalam mengelola kelas yang memfasilitasi kedua jenis gaya kognitif siswa untuk menumbuhkan kemampuan penalaran matematis siswa dalam menyelesaikan soal literasi matematika. 


\section{METODE}

Penelitian ini bertujuan untuk mendeskripsikan bagaimana kemampuan penalaran matematis siswa dalam menyelesaikan soal berbasis literasi matematika ditinjau dari gaya kognitif field independent dan field dependent. Oleh sebab itu, penelitian ini merupakan penelitian kualitatif. Subyek penelitian ini yaitu empat siswa kelas VIII SMP Negeri 2 Gunungwungkal yang masingmasing dikategorikan sebagai dua subyek bergaya kognitif field independent dan dua subyek bergaya kognitif field dependent. Pengambilan subyek dalam penelitian ini menggunakan purposive sampling. Subyek diambil atas saran dan pertimbangan dari guru mata pelajaran matematika di SMP Negeri 2 Gunungwungkal. Subyek dalam penelitian ini kemudian diberikan kode selanjutnya dapat dilihat dalam Tabel 1.. Dikarenakan adanya pandemi Covid-19 ini pengambilan data dilakukan dengan mendatangi masing-masing rumah siswa di luar jam pelajaran.

Tabel 1. Kode Subyek yang Terpilih

\begin{tabular}{ccc}
\hline No. & Kode Subyek & Kriteria Gaya Kognitif \\
\hline 1. & FD-01 & Field Dependent \\
2. & FD-02 & Field Dependent \\
3. & FI-01 & Field Independent \\
4. & FI-02 & Field Independent \\
\hline
\end{tabular}

Teknik pengumpulan data terdiri dari GEFT yang dikembangkan Witkin (1977) yaitu untuk mengklasifikasi siswa apakah siswa tersebut bertipe gaya kognitif field independent atau field dependent, tes penalaran matematika yang berupa tes uraian yang bertujuan untuk mengukur kemampuan penalaran matematis, wawancara untuk mengklarifikasi hasil jawaban subyek, dan dokumentasi untuk mendokumentasikan proses penelitian ini berlangsung sehingga dapat terekam dengan baik. GEFT sudah menjadi tes baku dalam pengukuran gaya kogniti, sehingga telah teruji validitas dan reliabilitasnya, serta dapat digunakan pada semua jenjang pendidikan. Dalam tes ini siswa harus menemukan gambar sederhana yang tersembunyi dalam gambar yang rumit (Sari, et. al., 2019). Pada tes penalaran matematika, telah dilakukan validasi ahli dan semua validator menyatakan valid, sehingga dapat dikatakan bahwa tes dengan tepat dapat mengukur konstruk penalaran matematika. Tes ini berbasis literasi matematika menggunakan materi pola pada barisan bilangan dan barisan konfigurasi objek, karena pada materi ini erat kaitannya dengan permasalahan dalam kehidupan sehari-hari yang penyelesaiannya membutuhkan kemampuan penalaran matematika. Literasi matematika tidak terlepas dari masalah di kehidupan nyata, maka dari itu siswa harus terbiasa dengan masalah-masalah yang ada di kehidupan nyata atau dalam kehidupan sehari-hari dan dapat menyelesaikannya dengan baik.

Analisis data pada penelitian ini menggunakan bantuan software yaitu QSR NVivo 11. Analisis dan visual pada penelitian ini dibuat dengan memanfaatkan fitur yang tersedia pada NVivo. Penelitian ini menggunakan metode interaktif yang terdiri dari tahap reduksi data, penyajian data, dan penarikan kesimpulan secara terus menerus hingga datanya jenuh (Miles \& Huberman, 2014). Tahap reduksi data untuk mengelompokkan sumber data yang sejenis yaitu hasil tes dan hasil wawancara dalam folder source terpisah pada sofware NVivo, dilanjutkan mengumpulkan informasi yang penting dan sejenis dalam nodes (coding). Tahap penyajian data yang dilakukan dalam penelitian ini dengan menggunakan fitur text search, word frequency, hierarchy chart, dan matrix coding pada NVivo. Tahap penarikan kesimpulan digunakan triangulasi meliputi triangulasi teknik, sumber, dan waktu (Gambar 1.). Untuk melakukan hal ini, pada software NVivo menggunakan fitur cluster analysis untuk mengetahui kesamaan kata yang terkandung pada sumber data atau node yang dipilih kemudian dibandingkan dengan comparison diagram. Salah satu hal mendasar yang harus diperhatikan oleh peneliti kualitatif yaitu mengukur akurasi dan konsistensi dalam penelitian (Sutrisno, et. al., 2019). Selanjutnya, untuk mengetahui tingkat reliabilitas dalam penelitian ini dapat diketahui dengan bantuan software QSR Nvivo pada fitur Coding Comparason Query (Muhtarom, et. al., 2017). Pada 
penelitian ini digunakan perhitungan rata-rata koefisien Kappa dengan pembobotan yang sama pada setiap sumber data (unweighted). Selanjutnya, rata-rata koefisien Kappa diinterpretasi menggunakan pedoman pada Tabel 2 .

Tabel 2. Pedoman Interprestasi Koefisien Kappa

\begin{tabular}{cc}
\hline Nilai Kappa & Interprestasi \\
\hline Kurang dari 0,40 & Poor Agreement \\
$0,40-0,75$ & Fair to Good Agreement \\
Lebih dari 0,75 & Excellent Agreement \\
\hline Sumber: Fleiss, et. al. (2003)\& QSR International (2016)
\end{tabular}

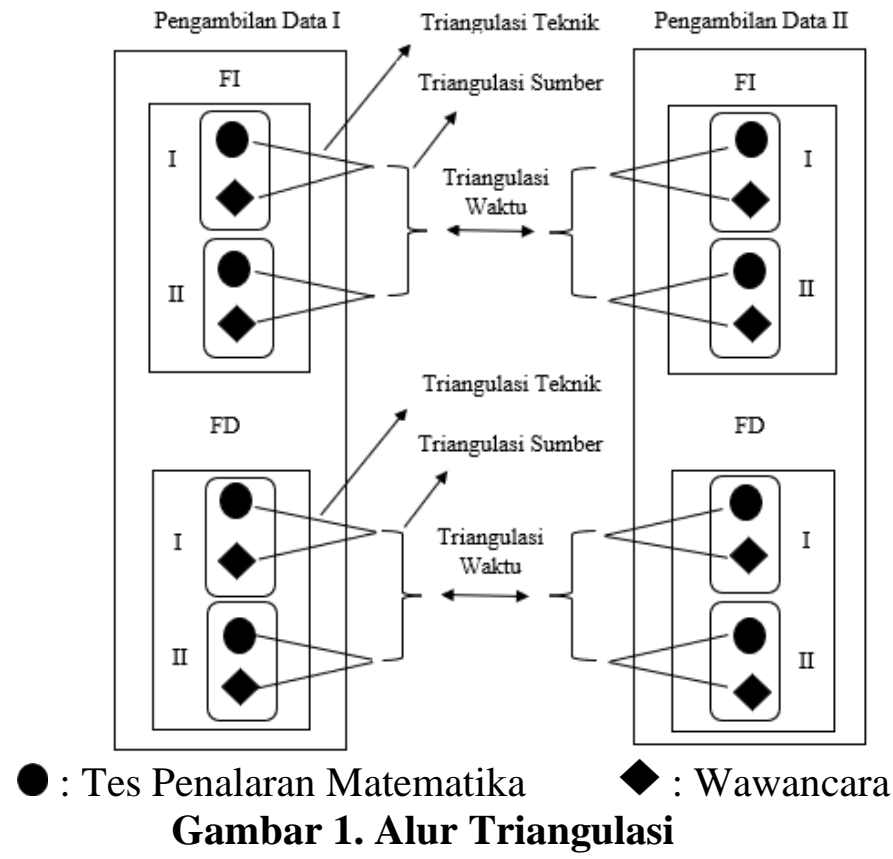

HASIL

Dengan menggunakan berbagai fitur yang terdapat pada software NVivo salah satunya yaitu fitur Word Frequency dari berbagai sumber yang telah diimport diperoleh kata yang terdominan yaitu kata "kemampuan" dengan persentase paling banyak yaitu 0,49\% dari semua sumber pada penelitian, kemudian diikuti dengan kata "kognitif", "matematis", dan "knowledge" yaitu 0,34, 0,3, dan 0,3. Hal itu tersaji pada Gambar 2. yang menunjukkan 50 kata terdominan yang digunakan dari sumber penelitian.

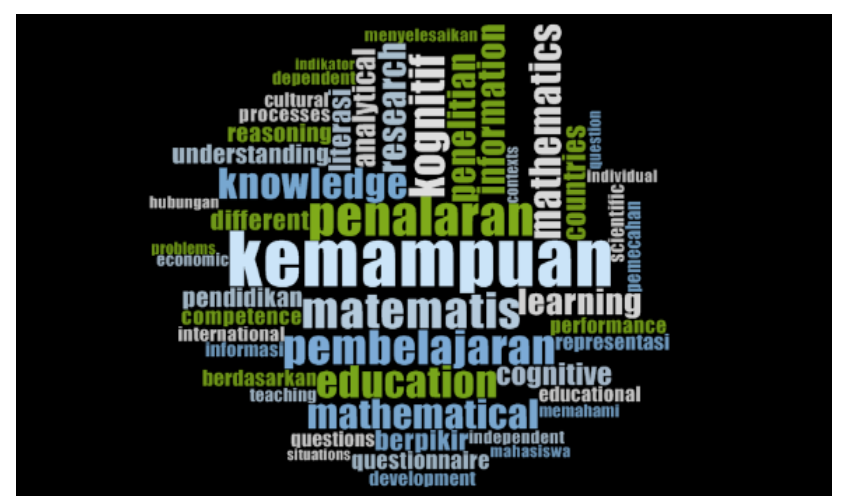

Gambar 2. Word Cloud 
Hasil penelitian ini menunjukkan bahwa jawaban tiap subyek berbeda-beda. Hal ini dapat diketahui melalui fitur Matrix Coding yang digunakan untuk mengetahui tahapan kemampuan penalaran matematis yang dilakukan setiap subyek yang tersaji pada Gambar 3.

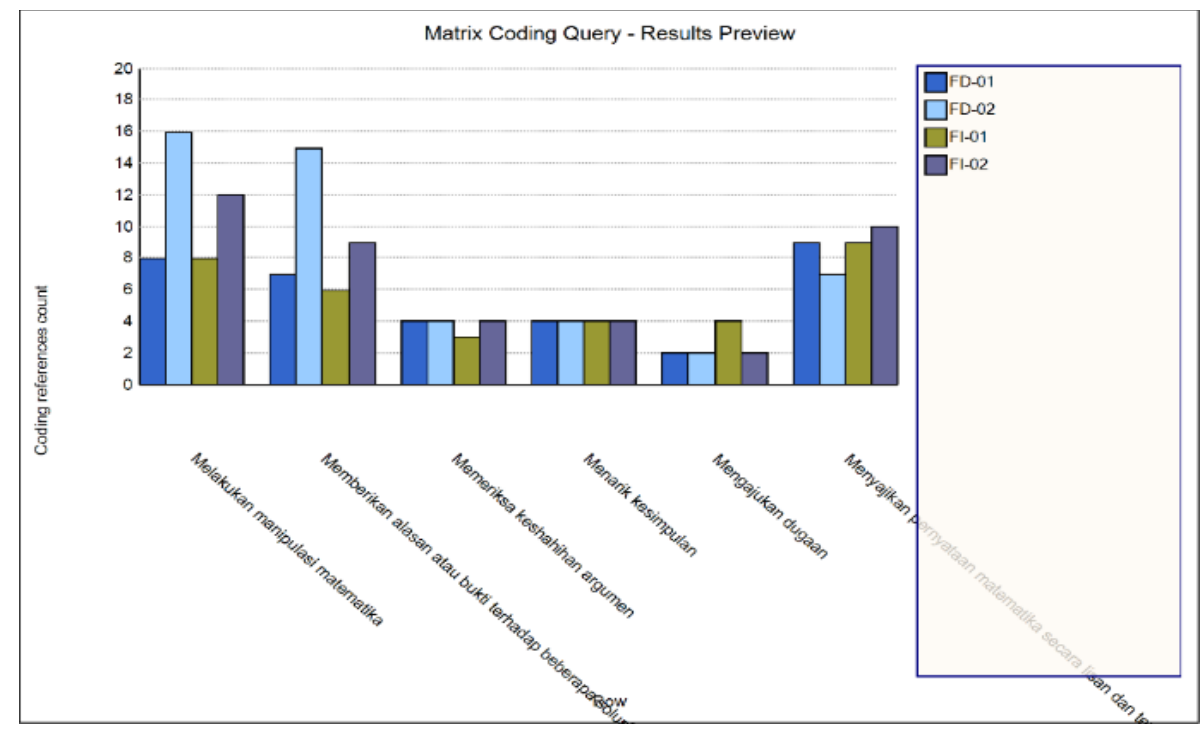

Gambar 3. Perbedaan Tahapan Kemampuan Penalaran Matematis pada Subyek Penelitian

Berdasarkan Gambar 2Gambar 3. diperoleh informasi bahwa dalam melakukan manipulasi matematika FD-02 memiliki kemampuan lebih tinggi daripada subyek lain, kemudian disusul oleh FI-02, FD-01, dan FI-01. Selanjutnya untuk tahap memberikan alasan atau bukti terhadap beberapa solusi juga terlihat FD-02 memiliki kemampuan lebih tinggi daripada subyek lain yang kemudian disusul subyek FI-02, FD-01, dan FI-01. Pada tahap memeriksa keshahihan argumen terihat subyek FD-01, FD-02, dan FI-02 memiliki kemampuan yang rendah yang kemudian disusul oleh subyek FI01 dikarenakan pada pengambilan data pertama subyek FI-01 terdapat kesalahan yang cukup banyak dlaam perhitungan. Pada tahap menarik kesimpulan semua subyek memiliki kemampuan yang rendah. Selanjutnya pada tahap mengajukan dugaan FI-01 lebih unggul sedikit daripada subyek yang lain dikarenakan subyek FD-01 dan FI-02 kurang mampu dalam mengajukan dugaan dan melakukan perhitungan secara tiba-tiba kemudian subyek FD-02 yang pada minggu pertama subyek kurang mampu dalam mengajukan dugaan. Pada tahap menyajikan pernyataan matematika secara lisan da tertulis terlihat bahwa subyek FD-02 memiliki kemampuan lebih tinggi daripada subyek lain yang kemudian disusul oleh subyek FD-01, FI-01, dan FD-02, pada tahap ini subyek FD-02 paling rendah karena pada saat pengambilan data pertama dan kedua subyek tidak menuliskan pernyataan matematika secara tertulis.

Berdasarkan hasil tes dan wawancara pada subyek penelitian dalam pengambilan data pertama diperoleh triangulasi teknik yang tersaji pada Tabel $3 .$.

Tabel 3. Triangulasi Teknik pada Pengambilan Data Pertama

\begin{tabular}{|c|c|c|c|}
\hline Subyek & Hasil Tes & Hasil Wawancara & Triangulasi Teknik \\
\hline FD-01 & $\begin{array}{l}\text { Subyek cukup mampu } \\
\text { dalam menyajikan } \\
\text { pernyataan matematika } \\
\text { secara tertulis, subyek } \\
\text { mampu dalam mengajukan } \\
\text { dugaan, subyek kurang } \\
\text { mampu dalam melakukan } \\
\text { manipulasi matematika, } \\
\text { memberikan alasan atau } \\
\text { bukti terhadap beberapa } \\
\text { solusi, menarik }\end{array}$ & $\begin{array}{l}\text { Subyek cukup mampu } \\
\text { dalam menyajikan } \\
\text { pernyataan matematika } \\
\text { secara tertulis, subyek } \\
\text { kurang mampu dalam } \\
\text { mengajukan dugaan, subyek } \\
\text { cukup mampu dalam } \\
\text { melakukan manipulasi } \\
\text { matematika, subyek kurang } \\
\text { mampu dalam memberikan } \\
\text { alasan atau bukti terhadap }\end{array}$ & $\begin{array}{l}\text { Subyek cukup mampu dalam } \\
\text { menyajikan pernyataan matematika } \\
\text { secara tertulis, mengajukan dugaan, } \\
\text { dan melakukan manipulasi } \\
\text { matematika, subyek kurang mampu } \\
\text { dalam memberikan alasan atau bukti } \\
\text { terhadap beberapa solusi, menarik } \\
\text { kesimpulan, dan memeriksa } \\
\text { keshahihan argumen. Berdasarkan } \\
\text { analisis diperoleh koefisien korelasi }\end{array}$ \\
\hline
\end{tabular}




\begin{tabular}{|c|c|c|c|}
\hline Subyek & Hasil Tes & Hasil Wawancara & Triangulasi Teknik \\
\hline & $\begin{array}{l}\text { kesimpulan, dan memeriksa } \\
\text { keshahihan argumen. }\end{array}$ & $\begin{array}{l}\text { beberapa solusi, menarik } \\
\text { kesimpulan, dan memeriksa } \\
\text { keshahihan argumen. }\end{array}$ & $\begin{array}{l}0,472669 \text { dengan kriteria fair to } \\
\text { good agreement. }\end{array}$ \\
\hline FD-02 & $\begin{array}{l}\text { Subyek tidak mampu dalam } \\
\text { menyajikan pernyataan } \\
\text { matematika secara tertulis, } \\
\text { subyek mampu dalam } \\
\text { mengajukan dugaan, } \\
\text { subyek tidak mampu dalam } \\
\text { melakukan manipulasi } \\
\text { matematika dan } \\
\text { memberikan alasan atau } \\
\text { bukti terhadap beberapa } \\
\text { solusi subyek kurang } \\
\text { mampu dalam menarik } \\
\text { kesimpulan, dan memeriksa } \\
\text { keshahihan argumen. }\end{array}$ & $\begin{array}{l}\text { Subyek kurang mampu } \\
\text { dalam menyajikan } \\
\text { pernyataan matematika } \\
\text { secara tertulis dan dalam } \\
\text { mengajukan dugaan, subyek } \\
\text { cukup mampu dalam } \\
\text { melakukan manipulasi } \\
\text { matematika ran dan } \\
\text { memberikan alasan atau } \\
\text { bukti terhadap beberapa } \\
\text { solusi, subyek kurang } \\
\text { mampu dalam menarik } \\
\text { kesimpulan dan memeriksa } \\
\text { keshahihan argumen. }\end{array}$ & $\begin{array}{l}\text { Subyek kurang mampu dalam } \\
\text { menyajikan pernyataan matematika } \\
\text { secara tertulis dan mengajukan } \\
\text { dugaan, subyek kurang mampu } \\
\text { dalam melakukan manipulasi } \\
\text { matematika, subyek kurang mampu } \\
\text { dalam memberikan alasan atau bukti } \\
\text { terhadap beberapa solusi, menarik } \\
\text { kesimpulan, dan memeriksa } \\
\text { keshahihan argumen. Berdasarkan } \\
\text { analisis diperoleh koefisien korelasi } \\
0,413092 \text { dengan kriteria fair to } \\
\text { good agreement. }\end{array}$ \\
\hline FI-01 & $\begin{array}{l}\text { Subyek mampu dalam } \\
\text { menyajikan pernyataan } \\
\text { matematika secara tertulis } \\
\text { dan mengajukan dugaan, } \\
\text { subyek cukup mampu } \\
\text { dalam melakukan } \\
\text { manipulasi matematika, } \\
\text { subyek kurang mampu } \\
\text { dalam memberikan alasan } \\
\text { atau bukti terhadap } \\
\text { beberapa solusi, menarik } \\
\text { kesimpulan, dan memeriksa } \\
\text { keshahihan argumen. }\end{array}$ & $\begin{array}{l}\text { Subyek mampu dalam } \\
\text { menyajikan pernyataan } \\
\text { matematika secara tertulis } \\
\text { dan mengajukan dugaan, } \\
\text { subyek cukup mampu dalam } \\
\text { melakukan manipulasi } \\
\text { matematika, subyek kurang } \\
\text { mampu dalam memberikan } \\
\text { alasan atau bukti terhadap } \\
\text { beberapa solusi, subyek } \\
\text { menarik kesimpulan, dan } \\
\text { memeriksa keshahihan } \\
\text { argumen. }\end{array}$ & $\begin{array}{l}\text { Subyek mampu dalam menyajikan } \\
\text { pernyataan matematika secara } \\
\text { tertulis, dan mengajukan dugaan, } \\
\text { subyek cukup mampu dalam } \\
\text { melakukan manipulasi matematika, } \\
\text { subyek kurang mampu dalam } \\
\text { memberikan alasan atau bukti } \\
\text { terhadap beberapa solusi, menarik } \\
\text { kesimpulan, dan memeriksa } \\
\text { keshahihan argumen. Berdasarkan } \\
\text { analisis diperoleh koefisien korelasi } \\
0,424242 \text { dengan kriteria fair to } \\
\text { good agreement. }\end{array}$ \\
\hline FI-02 & $\begin{array}{l}\text { Subyek mampu dalam } \\
\text { menyajikan pernyataan } \\
\text { matematika secara tertulis } \\
\text { dan mengajukan dugaan, } \\
\text { subyek cukup mampu } \\
\text { dalam melakukan } \\
\text { manipulasi matematika, } \\
\text { subyek kurang mampu } \\
\text { dalam memberikan alasan } \\
\text { atau bukti terhadap } \\
\text { beberapa solusi, menarik } \\
\text { kesimpulan, dan memeriksa } \\
\text { keshahihan argumen. }\end{array}$ & $\begin{array}{l}\text { Subyek mampu dalam } \\
\text { menyajikan pernyataan } \\
\text { matematika secara tertulis, } \\
\text { subyek kurang mampu } \\
\text { dalam mengajukan dugaan, } \\
\text { subyek cukup mampu dalam } \\
\text { melakukan manipulasi } \\
\text { matematika, subyek kurang } \\
\text { mampu dalam memberikan } \\
\text { alasan atau bukti terhadap } \\
\text { beberapa solusi, menarik } \\
\text { kesimpulan, dan memeriksa } \\
\text { keshahihan argumen. }\end{array}$ & $\begin{array}{l}\text { Subyek mampu dalam menyajikan } \\
\text { pernyataan matematika secara } \\
\text { tertulis, subyek cukup mampu } \\
\text { dalam mengajukan dugaan dan } \\
\text { melakukan manipulasi matematika, } \\
\text { subyek kurang mampu dalam } \\
\text { memberikan alasan atau bukti } \\
\text { terhadap beberapa solusi, menarik } \\
\text { kesimpulan, dan memeriksa } \\
\text { keshahihan argumen. Berdasarkan } \\
\text { analisis diperoleh koefisien korelasi } \\
\text { 0,415567 dengan kriteria fair to } \\
\text { good agreement. }\end{array}$ \\
\hline
\end{tabular}

Sumber: diolah dari data penelitian, 2021

Berdasarkan Tabel 3. diperoleh informasi bahwa keempat subyek memiliki korelasi yang hampir sama, namun dari masing-masing subyek terdapat perbedaan. Dari hasil tes kemampuan penalaran dan wawancara pada data pertama menunjukkan bahwa pada tahap menyajikan pernyataan matematika secara tertulis subyek FD-01 dan FD-02 cukup mampu dalam menyajikan pernyataan matematika secara tertulis sedangkan subyek FI-01 dan FI-02 mampu dalam menyajikan pernyataan matematika secara tertulis, pada tahap mengajukan dugaan subyek FD-01, FD-02, dan FI-02 cukup mampu dalam mengajukan dugaan sedangkan subyek FI-01 mampu dalam mengajukan dugaan, pada tahap melakukan manipulasi matematika subyek FD-02 kurang mampu dalam melakukan manipulasi matematika sedangkan subyek FD-01,FI-01, dan FI-02 cukup mampu dalam melakukan manipulasi matematika, pada tahap memberikan alasan atau bukti terhadap beberapa 
solusi subyek FD-01,FD-02,FI-01,dan FI-02 kurang mampu dalam memberikan alasan atau bukti terhadap beberapa solusi, pada tahap penarikan kesimpulan FD-01,FD-02,FI-01,dan FI-02 kurang mampu dalam menarik kesimpulan, dan pada tahap memeriksa keshahihan argumen subyek FD01,FD-02,FI-01,dan FI-02 kurang mampu dalam memeriksa keshahihan argumen. Untuk memeriksa kekonsistenan data yang dilakukan pada pengambilan data pertama, maka dilakukan pengambilan data kedua melalui tes kemampuan penalaran matematis dan wawancara.

Berdasarkan hasil tes dan wawancara pada subyek penelitian dalam pengambilan data kedua diperoleh triangulasi teknik yang tersaji pada Tabel $4 .$.

\section{Tabel 4. Triangulasi Teknik pada Pengambilan Data Kedua}

\begin{tabular}{|c|c|c|c|}
\hline Subyek & Hasil Tes & Hasil Wawancara & asi Teknik \\
\hline FD-01 & $\begin{array}{lr}\text { Subyek cukup mampu } \\
\text { dalam } & \text { menyajikan } \\
\text { pernyataan matematika } \\
\text { secara tertulis, mengajukan } \\
\text { dugaan, dan melakukan } \\
\text { manipulasi matematika, } \\
\text { subyek kurang mampu } \\
\text { dalam memberikan alasan } \\
\text { atau bukti r terhadap } \\
\text { beberapa solusi, menarik } \\
\text { kesimpulan, } \\
\text { memeriksa } \\
\text { argumen. }\end{array}$ & $\begin{array}{l}\text { Subyek cukup mampu dalam } \\
\text { menyajikan pernyataan } \\
\text { matematika secara lisan, } \\
\text { subyek kurang mampu dalam } \\
\text { mengajukan dugaan, subyek } \\
\text { cukup mampu dalam } \\
\text { melakukan manipulasi } \\
\text { matematika, subyek kurang } \\
\text { mampu dalam memberikan } \\
\text { alasan atau bukti terhadap } \\
\text { beberapa solusi, menarik } \\
\text { kesimpulan, dan memeriksa } \\
\text { keshahihan argumen. }\end{array}$ & $\begin{array}{l}\text { Subyek cukup mampu dalam } \\
\text { menyajikan pernyataan matematika } \\
\text { secara tertulis dan lisan, } \\
\text { mengajukan dugaan, dan } \\
\text { manipulasi matematika, subyek } \\
\text { kurang mampu dalam memberikan } \\
\text { alasan atau bukti terhadap beberapa } \\
\text { solusi, menarik kesimpulan, dan } \\
\text { memeriksa keshahihan argumen. } \\
\text { Berdasarkan analisis diperoleh } \\
\text { koefisien korelasi } 0,434519 \text { dengan } \\
\text { kriteria fair to good agreement. }\end{array}$ \\
\hline FD-02 & $\begin{array}{lr}\text { Subyek tidak mampu } \\
\text { dalam } & \text { menyajikan } \\
\text { pernyataan matematika } & \\
\text { secara tertulis, subyek } \\
\text { mampu dalam mengajukan } \\
\text { dugaan, } & \text { melakukan } \\
\text { manipulasi matematika, } \\
\text { memberikan alasan atau } \\
\text { bukti terhadap beberapa } \\
\text { solusi, } \\
\text { kesimpulan, menarik } \\
\text { memeriksa } \\
\text { argumen. }\end{array}$ & $\begin{array}{l}\text { Subyek cukup mampu dalam } \\
\text { menyajikan pernyataan } \\
\text { matematika secara lisan, } \\
\text { subyek kurang mampu dalam } \\
\text { mengajukan dugaan, subyek } \\
\text { mampu dalam melakukan } \\
\text { manipulasi matematika, } \\
\text { memberikan alasan atau bukti } \\
\text { terhadap beberapa solusi, } \\
\text { menarik kesimpulan, dan } \\
\text { memeriksa keshahihan } \\
\text { argumen. }\end{array}$ & $\begin{array}{l}\text { Subyek kurang mampu dalam } \\
\text { menyajikan pernyataan matematika } \\
\text { secara tertulis dan mengajukan } \\
\text { dugaan, subyek mampu dalam } \\
\text { melakukan manipulasi matematika, } \\
\text { memberikan alasan atau bukti } \\
\text { terhadap beberapa solusi, menarik } \\
\text { kesimpulan, dan memeriksa } \\
\text { keshahihan argumen. Berdasarkan } \\
\text { analisis diperoleh koefisien korelasi } \\
\text { 0,429298 dengan kriteria fair to } \\
\text { good agreement. }\end{array}$ \\
\hline FI-01 & $\begin{array}{l}\text { Subyek mampu dalam } \\
\text { menyajikan pernyataan } \\
\text { matematika secara tertulis, } \\
\text { mengajukan dugaan, } \\
\text { melakukan manipulasi } \\
\text { matematika, memberikan } \\
\text { alasan atau bukti terhadap } \\
\text { beberapa solusi, menarik } \\
\text { kesimpulan, dan } \\
\text { memeriksa keshahihan } \\
\text { argumen. }\end{array}$ & $\begin{array}{l}\text { Subyek mampu dalam } \\
\text { menyajikan pernyataan } \\
\text { matematika secara tertulis, } \\
\text { mengajukan dugaan, } \\
\text { melakukan manipulasi } \\
\text { matematika, memberikan } \\
\text { alasan atau bukti terhadap } \\
\text { beberapa solusi, menarik } \\
\text { kesimpulan, dan memeriksa } \\
\text { keshahihan argumen. }\end{array}$ & $\begin{array}{l}\text { Subyek mampu dalam menyajikan } \\
\text { pernyataan matematika secara } \\
\text { tertulis, mengajukan dugaan, } \\
\text { melakukan manipulasi matematika, } \\
\text { memberikan alasan atau bukti } \\
\text { terhadap beberapa solusi, menarik } \\
\text { kesimpulan, dan memeriksa } \\
\text { keshahihan argumen. Berdasarkan } \\
\text { analisis diperoleh koefisien korelasi } \\
0,551013 \text { dengan kriteria fair to } \\
\text { good agreement. }\end{array}$ \\
\hline FI-02 & $\begin{array}{l}\text { Subyek mampu dalam } \\
\text { menyajikan pernyataan } \\
\text { matematika secara tertulis } \\
\text { dan mengajukan dugaan, } \\
\text { subyek cukup mampu } \\
\text { dalam melakukan } \\
\text { manipulasi matematika, } \\
\text { subyek kurang mampu }\end{array}$ & $\begin{array}{l}\text { Subyek mampu dalam } \\
\text { menyajikan pernyataan } \\
\text { matematika secara tertulis, } \\
\text { subyek kurang mampu dalam } \\
\text { mengajukan dugaan, subyek } \\
\text { mampu dalam melakukan } \\
\text { manipulasi matematika, } \\
\text { subyek cukup mampu dalam }\end{array}$ & $\begin{array}{l}\text { Subyek mampu dalam menyajikan } \\
\text { pernyataan matematika secara } \\
\text { tertulis, subyek cukup mampu } \\
\text { dalam mengajukan dugaan, cukup } \\
\text { kurang mampu dalam melakukan } \\
\text { manipulasi matematika, subyek } \\
\text { cukup mampu dalam memberikan } \\
\text { alasan atau bukti terhadap beberapa }\end{array}$ \\
\hline
\end{tabular}




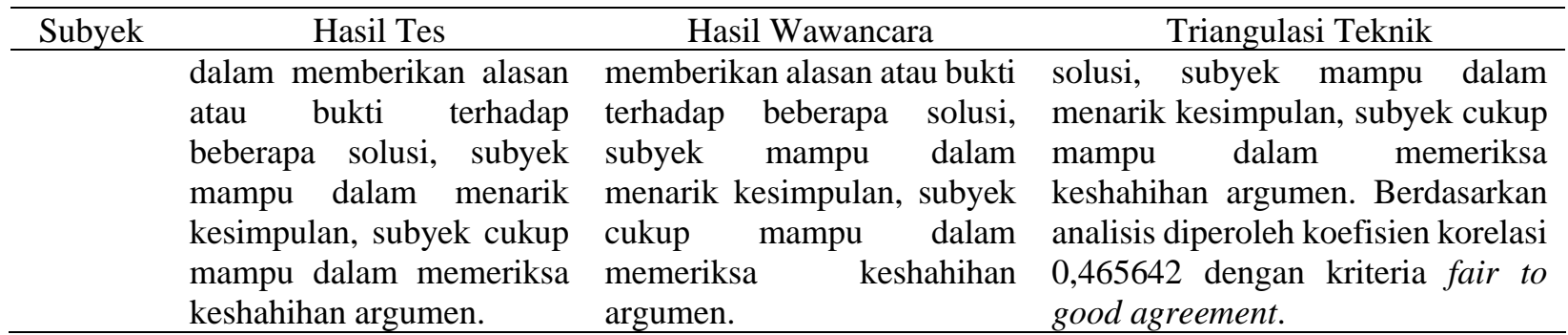

Sumber: diolah dari data penelitian, 2021

Berdasarkan Tabel 4. diperoleh informasi bahwa keempat subyek memiliki korelasi yang hampir sama, namun dari masing-masing subyek terdapat perbedaan. Dari hasil tes kemampuan penalaran dan wawancara pada data kedua menunjukkan bahwa pada tahap menyajikan pernyataan matematika secara tertulis subyek FD-01 dan FD-02 cukup mampu dalam menyajikan pernyataan matematika secara tertulis sedangkan subyek FI-01 dan FI-02 mampu dalam menyajikan pernyataan matematika secara tertulis, pada tahap mengajukan dugaan subyek FD-01,FD-02,dan FI-02 cukup mampu dalam mengajukan dugaan sedangkan subyek FI-01 mampu dalam mengajukan dugaan, pada tahap melakukan manipulasi matematika subyek subyek FD-01 cukup mampu dalam melakukan manipulasi matematika sedangkan subyek FD-02,FI-01, dan FI-02 mampu dalam melakukan manipulasi matematika, pada tahap memberikan alasan atau bukti terhadap beberapa solusi subyek subyek FD-01 kurang mampu dalam memberikan alasan atau bukti terhadap beberapa solusi kemudian subyek FI-02 cukup mampu dalam memberikan alasan atau bukti terhadap beberapa solusi sedangkan subyek FD-02 dan FI-01 mampu dalam memberikan alasan atau bukti terhadap beberapa solusi, pada tahap penarikan kesimpulan FD-01 kurang mampu dalam menarik kesimpulan sedangkan FD-02,FI-01, dan FI-02 mampu dalam menarik kesimpulan, dan pada tahap memeriksa keshahihan argumen subyek subyek FD-01 kurang mampu dalam memeriksa kesahihan argumen kemudian subyek FI-02 cukup mampu dalam memeriksa kesahihan argumen sedangkan subyek FD02 dan FI-01 mampu dalam memeriksa keshahihan argumen.

Dari hasil triangulasi teknik dari keempat subyek pada pengambailan data pertama dan pengambilan data kedua, diperoleh triangulasi sumber yang tersaji pada Tabel 5. .

\section{Tabel 5. Triangulasi Sumber}

\begin{tabular}{|c|c|c|c|c|}
\hline Subyek & Pertama & Triangula & Kedua & \\
\hline & $\begin{array}{l}\text { Subyek cukup mampu } \\
\text { dalam menyajikan } \\
\text { pernyataan matematika } \\
\text { secara tertulis dan lisan, } \\
\text { mengajukan dugaan dan } \\
\text { melakukan manipulasi } \\
\text { matematika, subyek } \\
\text { kurang mampu dalam } \\
\text { memberikan alasan atau } \\
\text { bukti terhadap beberapa } \\
\text { solusi, menarik } \\
\text { kesimpulan } \\
\text { memeriksa keshahihan } \\
\text { argumen. }\end{array}$ & $\begin{array}{l}\text { Kedua subyek field } \\
\text { dependent kurang mampu } \\
\text { dalam menyajikan } \\
\text { pernyataan matematika } \\
\text { secara tertulis, kedua } \\
\text { subyek field dependent } \\
\text { cukup mampu dalam } \\
\text { mengajukan dugaan, } \\
\text { subyek field dependent } \\
\text { kurang mampu dalam } \\
\text { melakukan manipulasi } \\
\text { matematika namun ada } \\
\text { subyek field dependent } \\
\text { yang cukup mampu } \\
\text { dalam manipulasi }\end{array}$ & $\begin{array}{l}\text { Subyek cukup mampu } \\
\text { dalam menyajikan } \\
\text { pernyataan matematika } \\
\text { secara tertulis dan lisan, } \\
\text { mengajukan dugaan, } \\
\text { dan melakukan } \\
\text { manipulasi matematika, } \\
\text { subyek kurang mampu } \\
\text { dalam memberikan } \\
\text { alasan ataur bukti } \\
\text { terhadap beberapa } \\
\text { solusi, } \\
\text { kesimpulan, menarik } \\
\text { memeriksa keshahihan } \\
\text { argumen. }\end{array}$ & 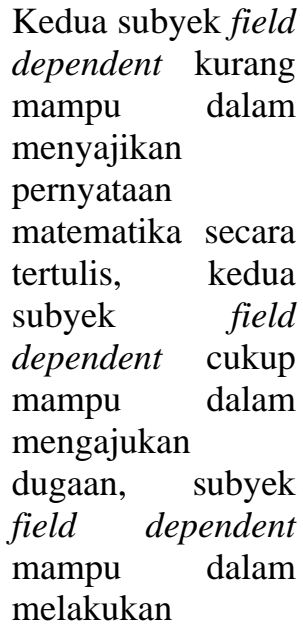 \\
\hline FD-02 & $\begin{array}{l}\text { ubyek kurang mampu } \\
\text { alam menyajikan } \\
\text { ernyataan matematika } \\
\text { ecara tertulis, subyek } \\
\text { ukup mampu dalam } \\
\text { engajukan dugaan, }\end{array}$ & $\begin{array}{l}\text { matematika, kedua } \\
\text { subyek field dependent } \\
\text { kurang mampu dalam } \\
\text { memberikan alasan atau } \\
\text { bukti terhadap beberapa } \\
\text { solusi, menarik }\end{array}$ & $\begin{array}{l}\text { Subyek kurang mampu } \\
\text { dalam menyajikan } \\
\text { pernyataan matematika } \\
\text { secara tertulis, subyek } \\
\text { cukup mampu dalam } \\
\text { mengajukan dugaan, }\end{array}$ & $\begin{array}{l}\text { manipulasi } \\
\text { matematika meski } \\
\text { ada subyek field } \\
\text { dependent yang } \\
\text { cukup mampu } \\
\text { dalam melakukan }\end{array}$ \\
\hline
\end{tabular}




\begin{tabular}{|c|c|c|c|c|}
\hline Subyek & $\begin{array}{c}\text { Pengambilan Data } \\
\text { Pertama }\end{array}$ & Triangulasi Sumber & $\begin{array}{c}\text { Pengambilan Data } \\
\text { Kedua }\end{array}$ & Trianglasi Sumber \\
\hline \multirow[b]{2}{*}{ FI-01 } & $\begin{array}{l}\text { subyek kurang mampu } \\
\text { dalam melakukan } \\
\text { manipulasi matematika, } \\
\text { memberikan alasan atau } \\
\text { bukti terhadap beberapa } \\
\text { solusi, menarik } \\
\text { kesimpulan, dan } \\
\text { memeriksa keshahihan } \\
\text { argumen. }\end{array}$ & $\begin{array}{lr}\text { kesimpulan, } & \text { dan } \\
\text { memeriksa } & \text { keshahihan } \\
\text { argumen. } & \end{array}$ & $\begin{array}{l}\text { subyek mampu dalam } \\
\text { melakukan manipulasi } \\
\text { matematika, } \\
\text { memberikan alasan atau } \\
\text { bukti terhadap beberapa } \\
\text { solusi, menarik } \\
\text { kesimpulan, dan } \\
\text { memeriksa keshahihan } \\
\text { argumen. }\end{array}$ & 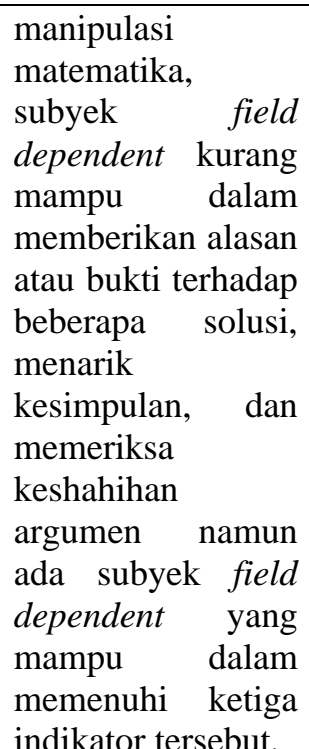 \\
\hline & $\begin{array}{l}\text { Subyek mampu dalam } \\
\text { menyajikan pernyataan } \\
\text { matematika rara secara } \\
\text { tertulis, mengajukan } \\
\text { dugaan, dan melakukan } \\
\text { manipulasi matematika, } \\
\text { subyek kurang mampu } \\
\text { dalam memberikan } \\
\text { alasan atau bukti } \\
\text { terhadap beberapa } \\
\text { solusi, ran } \\
\text { kesimpulan, menarik } \\
\text { memeriksa keshahihan } \\
\text { argumen. }\end{array}$ & $\begin{array}{l}\text { Kedua subyek field } \\
\text { independent mampu } \\
\text { dalam menyajikan } \\
\text { pernyataan matematika } \\
\text { secara tertulis, subyek } \\
\text { field independent mampu } \\
\text { dalam mengajukan } \\
\text { dugaan meskipun ada } \\
\text { subyek field independent } \\
\text { yang cukup mampu } \\
\text { dalam mengajukan } \\
\text { dugaan, kedua subyek } \\
\text { field independent cukup } \\
\text { mampu dalam melakukan }\end{array}$ & $\begin{array}{l}\text { Subyek mampu dalam } \\
\text { menyajikan pernyataan } \\
\text { matematika secara } \\
\text { tertulis, mengajukan } \\
\text { dugaan, melakukan } \\
\text { manipulasi matematika, } \\
\text { memberikan alasan atau } \\
\text { bukti terhadap beberapa } \\
\text { solusi, rik } \\
\text { kesimpulan, menarik } \\
\text { memeriksa keshahihan } \\
\text { argumen. }\end{array}$ & \multirow{2}{*}{$\begin{array}{l}\text { Kedua subyek field } \\
\text { independent } \\
\text { mampu dalam } \\
\text { menyajikan } \\
\text { pernyataan } \\
\text { matematika secara } \\
\text { tertulis, } \\
\text { mengajukan } \\
\text { dugaan, melakukan } \\
\text { manipulasi } \\
\text { matematika, } \\
\text { memberikan alasan } \\
\text { atau bukti terhadap } \\
\text { beberapa solusi } \\
\text { menarik } \\
\text { kesimpulan, dan } \\
\text { memeriksa } \\
\text { keshahihan } \\
\text { argument. }\end{array}$} \\
\hline FI-02 & 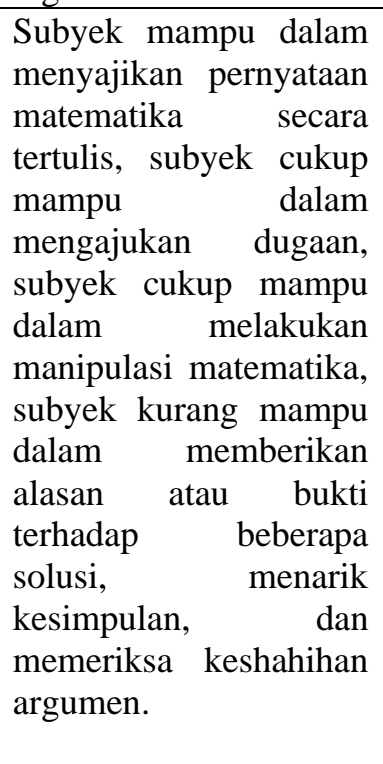 & \begin{tabular}{lr}
\multicolumn{2}{l}{ manipulasi matematika, } \\
kedua subyek field \\
independent & kurang \\
mampu & dalam \\
memberikan alasan atau \\
bukti terhadap beberapa \\
solusi, kedua subyek field \\
independent $r$ kurang \\
mampu dalam menarik \\
kesimpulan, r kedua \\
subyek field independent \\
kurang mampu dalam \\
memeriksa keshahihan \\
argumen.
\end{tabular} & \begin{tabular}{lr}
\multicolumn{2}{l}{ Subyek mampu dalam } \\
menyajikan pernyataan \\
matematika & secara \\
tertulis, subyek & cukup \\
mampu & dalam \\
mengajukan & dugaan, \\
mampu & dalam \\
melakukan manipulasi \\
matematika, subyek \\
cukup mampu dalam \\
memberikan alasan atau \\
bukti terhadap beberapa \\
solusi, subyek mampu \\
dalam & menarik \\
kesimpulan, subyek \\
cukup mampu dalam \\
memeriksa keshahihan \\
argumen.
\end{tabular} & \\
\hline
\end{tabular}

Sumber: diolah dari data penelitian, 2021

Berdasarkan Tabel 5. diperoleh triangulasi sumber pada pengambilan data pertama pada subyek field dependent yaitu kedua subyek field dependent kurang mampu dalam menyajikan pernyataan matematika secara tertulis, kedua subyek field dependent cukup mampu dalam mengajukan dugaan, subyek field dependent kurang mampu dalam melakukan manipulasi matematika namun ada subyek 
field dependent yang cukup mampu dalam manipulasi matematika, kedua subyek field dependent kurang mampu dalam memberikan alasan atau bukti terhadap beberapa solusi, menarik kesimpulan, dan memeriksa keshahihan argumen. Sedangkan pada subyek field independent kedua subyek field independent mampu dalam menyajikan pernyataan matematika secara tertulis, subyek field independent mampu dalam mengajukan dugaan meskipun ada subyek field independent yang cukup mampu dalam mengajukan dugaan, kedua subyek field independent cukup mampu dalam melakukan manipulasi matematika, kedua subyek field independent kurang mampu dalam memberikan alasan atau bukti terhadap beberapa solusi, kedua subyek field independent kurang mampu dalam menarik kesimpulan, kedua subyek field independent kurang mampu dalam memeriksa keshahihan argumen.

Pada pengambilan data kedua subyek field dependent diperoleh informasi bahwa kedua subyek field dependent kurang mampu dalam menyajikan pernyataan matematika secara tertulis, kedua subyek field dependent cukup mampu dalam mengajukan dugaan, subyek field dependent mampu dalam melakukan manipulasi matematika meski ada subyek field dependent yang cukup mampu dalam melakukan manipulasi matematika, subyek field dependent kurang mampu dalam memberikan alasan atau bukti terhadap beberapa solusi, menarik kesimpulan, dan memeriksa keshahihan argumen namun ada subyek field dependent yang mampu dalam memenuhi ketiga indikator tersebut. Sedangkan pada subyek field independent diperoleh informasi bahwa subyek memenuhi keenam indikator.

Berdasarkan tringulasi sumber pada pengambilan data pertama dan pengambilan data kedua diperoleh triangulasi waktu yang tersaji pada Tabel 6 ..

\section{Tabel 6. Triangulasi Waktu}

\begin{tabular}{|c|c|c|c|}
\hline Su & $\begin{array}{l}\text { Triangulasi Sumber pada } \\
\text { Pengambilan Data Pertama }\end{array}$ & $\begin{array}{l}\text { Triangulasi Sumber pada } \\
\text { Pengambilan Data Kedua }\end{array}$ & $\mathbf{u}$ \\
\hline $\begin{array}{l}\text { Field } \\
\text { Depende }\end{array}$ & $\begin{array}{l}\text { Kedua subyek field dependent } \\
\text { kurang mampu dalam } \\
\text { menyajikan pernyataan } \\
\text { matematika secara tertulis, } \\
\text { kedua subyek field dependent } \\
\text { cukup mampu dalam } \\
\text { mengajukan dugaan, subyek } \\
\text { field dependent kurang } \\
\text { mampu dalam melakukan } \\
\text { manipulasi matematika } \\
\text { namun ada subyek field } \\
\text { dependent yang cukup } \\
\text { mampu dalam manipulasi } \\
\text { matematika, kedua subyek } \\
\text { field dependent kurang } \\
\text { mampu dalam memberikan } \\
\text { alasan atau bukti terhadap } \\
\text { beberapa solusi, menarik } \\
\text { kesimpulan, dan memeriksa } \\
\text { keshahihan argumen. }\end{array}$ & $\begin{array}{l}\text { Kedua subyek field dependent } \\
\text { kurang mampur dalam } \\
\text { menyajikan pernyataan } \\
\text { matematika secara tertulis, } \\
\text { kedua subyek field dependent } \\
\text { cukup mampu dalam } \\
\text { mengajukan dugaan, subyek } \\
\text { field dependent mampu dalam } \\
\text { melakukan manipulasi } \\
\text { matematika meski ada subyek } \\
\text { field dependent yang cukup } \\
\text { mampu dalam melakukan } \\
\text { manipulasi matematika, subyek } \\
\text { field dependent kurang mampu } \\
\text { dalam memberikan alasan atau } \\
\text { bukti terhadap beberapa solusi, } \\
\text { menarik kesimpulan, dan } \\
\text { memeriksa keshahihan argumen } \\
\text { namun ada subyek field } \\
\text { dependent yang mampu dalam } \\
\text { memenuhi ketiga indikator } \\
\text { tersebut. }\end{array}$ & $\begin{array}{l}\text { Kedua subyek field } \\
\text { dependent kurang mampu } \\
\text { dalam menyajikan } \\
\text { pernyataan matematika } \\
\text { secara tertulis, Kedua } \\
\text { subyek field dependent } \\
\text { cukup mampu dalam } \\
\text { mengajukan dugaan dan } \\
\text { melakukan manipulasi } \\
\text { matematika, subyek field } \\
\text { dependent kurang mampu } \\
\text { dalam memberikan alasan } \\
\text { atau bukti terhadap } \\
\text { beberapa solusi, menarik } \\
\text { kesimpulan, memeriksa } \\
\text { keshahihan argument. }\end{array}$ \\
\hline $\begin{array}{l}\text { Field } \\
\text { Indepenc }\end{array}$ & $\begin{array}{l}\text { Kedua subyek field } \\
\text { independent mampu dalam } \\
\text { menyajikan } \\
\text { matematika secara tertulis, } \\
\text { subyek field independent } \\
\text { mampu dalam mengajukan } \\
\text { dugaan meskipun ada subyek } \\
\text { field independent yang cukup }\end{array}$ & $\begin{array}{l}\text { Kedua subyek field independent } \\
\text { mampu dalam menyajikan } \\
\text { pernyataan matematika secara } \\
\text { tertulis, mengajukan dugaan, } \\
\text { melakukan manipulasi } \\
\text { matematika, memberikan alasan } \\
\text { atau bukti terhadap beberapa } \\
\text { solusi menarik kesimpulan, dan }\end{array}$ & $\begin{array}{lr}\text { Kedua subyek } & \text { field } \\
\text { independent } & \text { mampu } \\
\text { dalam } & \text { menyajikan } \\
\text { pernyataan } & \text { matematika } \\
\text { secara } & \text { tertulis, } \\
\text { mengajukan } & \text { dugaan, } \\
\text { kedua subyek } & \text { field } \\
\text { independent } & \text { mampu }\end{array}$ \\
\hline
\end{tabular}




\begin{tabular}{|c|c|c|c|}
\hline Subyek & $\begin{array}{l}\text { Triangulasi Sumber pada } \\
\text { Pengambilan Data Pertama }\end{array}$ & $\begin{array}{l}\text { Triangulasi Sumber pada } \\
\text { Pengambilan Data Kedua }\end{array}$ & Triangulasi Waktu \\
\hline & $\begin{array}{l}\text { mampu dalam mengajukan } \\
\text { dugaan, kedua subyek field } \\
\text { independent cukup mampu } \\
\text { dalam melakukan manipulasi } \\
\text { matematika, kedua subyek } \\
\text { field independent kurang } \\
\text { mampu dalam memberikan } \\
\text { alasan atau bukti terhadap } \\
\text { beberapa solusi, kedua } \\
\text { subyek field independent } \\
\text { kurang mampu dalam } \\
\text { menarik kesimpulan, kedua } \\
\text { subyek field independent } \\
\text { kurang mampu dalam } \\
\text { memeriksa keshahihan } \\
\text { argumen. }\end{array}$ & $\begin{array}{l}\text { memeriksa } \\
\text { argument. }\end{array}$ & \begin{tabular}{lr} 
dalam & \multicolumn{2}{r}{ melakukan } \\
manipulasi matematika, & medua subyek field \\
kedependent & cukup \\
indepen & dalam \\
mampu & memberikan alasan atau \\
bukti terhadap beberapa \\
solusi, & menarik \\
kesimpulan, & dan \\
memeriksa & keshahihan \\
argumen. &
\end{tabular} \\
\hline
\end{tabular}

Sumber: diolah dari data penelitian, 2021

Dalam penelitian kualitatif hal yang harus diperhatikan yaitu bagaimana mengukur akurasi dan konsistensi penelitian. Oleh sebab itu dengan adanya software NVivo pada fitur Coding Comparison sebagai bantuan untuk membandingkan hasil koding yang telah dilakukan oleh dua pengguna. Fitur ini menyediakan cara untuk mengukur tingkat kesepakatan antar pengguna melalui koefisien Cohen's Kappa atau biasa dikenal sebagai koefisien Kappa. Uji Kappa digunakan untuk menentukan konsistensi hasil koding antar anggota pengguna. Koefisien Kappa memperhitungkan jumlah kesepakatan yang diharapkan terjadi secara kebetulan.

Pada penelitian ini, diperoleh rata-rata koefisien Kappa sebesar 0,953918 dengan presentase kesepakatan mencapai 93,37\%. Interpretasi nilai koefisien Kappa dapat dilihat pada Tabel 2 tentang Interpretasi Koefisien Kappa Query (Muhtarom, et. al., 2017), sehingga diperoleh kesimpulan bahwa dengan koefisien Kappa sebesar 0,953918 yang berada lebih dari 0,75 maka reabilitas penelitian ini tergolong Excellent Agreement.

Berdasarkan analisis data yang dilakukan, diperoleh hasil tes kemampuan penalaran matematis dalam menyelesaikan soal berbasis literasi matematika ditinjau dari gaya kognitif field independent dan field dependent mencapai hasil yang cukup baik. Banyak siswa yang kurang teliti dalam memeriksa kembali jawabannya. Beberapa siswa masih kurang memahami konsep dasar sehingga berujung pada penyelesaian yang kurang tepat. Terdapat beberapa siswa yang merasa kebingungan dalam menjawab soal, hal ini terlihat pada jawaban siswa pada langkah penyelesaian yang banyak dengan coretan.

\section{PEMBAHASAN}

Gaya kognitif adalah merupakan karakteristik setiap individu dalam menerima, mengingat, dan mengorganisasikan informasi untuk menanggapi suatu tugas. Di sisi lain, gaya kognitif adalah karakteristik individu dalam penggunaan fungsi kognitif (berpikir, mengingat, memecahkan masalah, membuat keputusan) (Desmita, 2012). Hal ini sejalan dengan Messick bahwa gaya kognitif merupakan karakteristik individu dalam memahami lingkungannya secara konsisten seperti mengingat, berpikir, memecahkan masalah, dan mengambil keputusan (Putra, et. al., 2013). Dengan perbedaan gaya kognitif, siswa yang bergaya kognitif field dependent dan field independent memiliki perbedaan pola pikir dan cara menyelesaikan masalah (Hidayat, et. al., 2013).

Siswa yang memiliki tipe gaya kognitif yaitu field dependent memiliki kemampuan penalaran yang baik. Siswa dengan gaya kognitif field dependent cenderung belajar secara berkelompok dan seringkali berinteraksi dengan siswa, guru, maupun lingkungan sekitar. Sejalan dengan itu, peserta 
didik dengan gaya kognitif field dependent sangat dipengaruhi oleh lingkungan atau bergantung pada lingkungan (Nasution, 2006). Sedangkan siswa yang memiliki tipe gaya kognitif yaitu field independent pada umumnya memiliki kemampuan penalaran matematis yang sangat baik. Dikuatkan dengan hasil penelitian, subyek yang memiliki gaya kognitif field independent melakukan aktivitas mengumpulkan fakta, menyusun dan menguji dugaan, memberikan argumen, dan membuat kesimpulan yang logis dalam memahami masalah, menyusun rencana penyelesaian, melaksanakan rencana, dan memeriksa kembali (Haryanti \& Masriyah, 2018). Siswa bergaya kognitif field independent menerima dan mengolah seluruh informasi secara analitis sehingga siswa bergaya kognitif field independent melakukan seluruh aktivitas penalaran matematika. Adapun hasil penelitian lain menyimpulkan bahwa penalaran siswa dengan kemampuan gaya kognitif field independent cenderung hampir memenuhi penalaran, yaitu mampu menyajikan pernyataan matemtika secara lisan dan tertulis, mengajukan dugaan, melakukan manipulasi matematika, memberikan alasan atau bukti terhadap beberapa solusi, menarik kesimpulan dari pernyataan, memeriksa keshahihan argumen, dan menemukan pola untuk membuat generalisasi (Irdhiyanti, 2019).

Berdasarkan hasil analisis yang telah dilakukan terhadap subyek bergaya kognitif field dependent dan field independent terdapat perbedaan kemampuan penalaran matematis yang dapat disajikan pada Tabel 7. .

Tabel 7. Perbedaan Kemampuan Penalaran Matematis Siswa Bergaya Kognitif Field Dependent dan Field Independent

\begin{tabular}{llcc}
\hline \multirow{2}{*}{ No } & \multicolumn{1}{c}{ Indikator } & \multicolumn{2}{c}{ Kategori } \\
\cline { 3 - 4 } & & Field Dependent & Field Independent \\
\hline 1. & Menyajikan pernyataan matematika secara lisan dan tertulis. & Kurang Mampu & Mampu \\
2. & Mengajukan dugaan & Cukup & Mampu \\
3. & Melakukan manipulasi matematika & Cukup & Mampu \\
4. & Memberikan alasan atau bukti terhadap beberapa solusi. & Kurang Mampu & Cukup mampu \\
5. & Menarik kesimpulan & Kurang Mampu & Cukup mampu \\
6. & Memeriksa keshahihan argument & Kurang Mampu & Cukup mampu \\
\hline
\end{tabular}

Sumber: diolah dari data penelitian, 2021

Mengacu pada Tabel 7., terlihat bahwa subyek field dependent kurang mampu dalam menyajikan pernyataan matematika secara lisan dan tertulis hal ini disebabkan karena terdapat subyek field dependent yang kurang tepat dalam menyajikan pernyataan matematika dan ada juga yang tidak menyajikan pernyataan matematika tertulis sebelum melangkah pada tahap perhitungan. Namun pada indikator mengajukan dugaan dan melakukan manipulasi matematika subyek field dependent cukup mampu dalam melakukannya. Subyek field dependent kurang mampu dalam memberikan alasan atau bukti terhadap beberapa solusi, menarik kesimpulan, dan memeriksa kesahihan argumen dikarenakan subyek kurang menguasai konsep materi dan kurang tepat dalam perhitungan sehingga menghasilkan kesimpulan yang kurang tepat. Hal ini didukung dengan hasil penelitian yang telah ada, kelemahan yang ada pada siswa antara lain, kurang memiliki kemmapuan untuk memahami serta mengenali konsep-konsep dasar matematika (aksioma, kaidah, definisi, teorema) (Fuadi, et. al., 2016). Adapun hasil penelitian lain menyebutkan bahwa kategori gaya kognitif field dependent mempunyai kendala tidak mampu menentukan pola atau sifat dari gejala matematis, tidak bisa membuat kesimpulan umum dari jawaban yang diberikan (Utami, 2020).

Subyek field independent hampir memenuhi semua indikator kemampuan penalaran matematis hanya saja subyek cukup mampu dalam memberikan alasan atau bukti terhadap beberapa solusi, 
menarik kesimpulan, dan memeriksa kesahihan argumen dikarenakan subyek field independent kurang maksimal dalam menjawab soal sehingga terdapat beberapa kesalahan dalam perhitungannya. Adapun hasil penelitian lain mampu menguji dugaan sesuai dengan strategi pemecahan masalah yang telah disusun dengan tepat dan menggunakan hubungan-hubungan yang telah dibuat untuk mencapai solusi, mampu menyusun bukti terhadap solusi yang diperoleh dengan menuliskan proses perhitungan secara sistematis, lengkap dan jelas sehingga menghasilkan solusi yang tepat, mampu memberikan alasan logis terhadap kebenaran solusi yang diperoleh, dan mampu menarik kesimpulan dengan tepat (Yekti, et. al., 2016). Berdasarkan Tabel 7. terlihat bahwa subyek field independent lebih unggul daripada subyek field dependent dalam kemampuan penalaran matematis.

\section{SIMPULAN}

Berdasarkan hasil penelitian dan pembahasan yang telah dilakukan terkait dengan kemampuan penalaran matematis siswa dalam menyelesaikan soal berbasis literasi matematika ditinjau dari gaya kognitif field independent dan field dependent dengan empat subyek utama dalam penelitian ini. Maka dapat disimpulkan sebagai berikut: (1) Siswa field independent cukup mampu menguasai hampir semua indikator kemampuan penalaran matematis. Siswa field independent mampu dalam menyajikan pernyataan matematika secara lisan dan tertulis. Mampu dalam mengajukan dugaan. Mampu dalam melakukan manipulasi. Cukup mampu dalam memberikan alasan atau bukti terhadap beberapa solusi meskipun terdapat subyek yang kurang mampu dalam memberikan alasan atau bukti terhadap beberapa solusi. Cukup mampu dalam menarik kesimpulan. Cukup mampu dalam memeriksa keshahihan argumen. (2) Siswa field dependent cukup mampu menguasai dua indikator kemampuan penalaran matematis. Siswa field dependent kurang mampu dalam menyajikan pernyataan matematika secara lisan dan tertulis. Cukup mampu dalam mengajukan dugaan. Cukup mampu dalam melakukan manipulasi matematika. Kurang mampu dalam memberikan alasan atau bukti terhadap beberapa solusi. Kurang mampu dalam menarik kesimpulan. Kurang mampu dalam memeriksa keshahihan argumen.

Dalam penelitian ini tentunya memiliki keterbatasan-keterbatasan yang dapat mempengaruhi hasil penelitian di antaranya keterbatasan waktu penelitian. Waktu penelitian yang singkat membuat ruang gerak penelitian menjadi sempit. Waktu yang tersedia disesuaikan dengan materi ajar terkait penelitian yaitu pola pada barisan bilangan dan barisan konfigurasi objek kelas VIII semester 1, yang terpaut cukup jauh dengan pelaksanaan penelitian pada semester 2 . Untuk penelitian selanjutnya, disarankan dilakukan dengan rentang waktu yang tidak terpaut jauh dari pelaksanaan pembelajaran oleh guru pada materi yang dijadikan topik penelitian.

\section{DAFTAR RUJUKAN}

Agustin, R. D. (2016). Kemampuan Penalaran Matematika Mahasiswa Melalui Pendekatan Problem Solving. PEDAGOGIA: Jurnal Pendidikan, 5(2), 179-188. https://doi.org/10.21070/pedagogia.v5i2.249

Asmara, A. S., Waluya, S. B., \& Rochmad. (2017). Analisis Kemampuan Literasi Matematika Siswa Kelas X Berdasarkan Kemampuan Matematika. Scholaria, 7(2), 135-142. https://ejournal.uksw.edu/scholaria/article/download/965/515/

Depdiknas. (2006). Permen Nomor 22 Tahun 2006. Depdiknas.

Desmita. (2012). Psikologi Perkembangan Peserta Didik. Bandung: Rosda Karya.

Fleiss, J. L., Levin, B., \& Paik, M. C. (2003). Statistical Methods for Rates and Proportions. New York: Wiley \& Sons.

Fuadi, R., Johar, R., \& Munzir, S. (2016). Peningkatkan Kemampuan Pemahaman dan Penalaran Matematis melalui Pendekatan Kontekstual. Jurnal Didaktik Matematika, 3(1), 47-54. https://doi.org/10.24815/jdm.v3i1.4305 
Haryanti, C. F., \& Masriyah. (2018). Profil Penalaran Matematika Siswa SMP dalam Memecahkan Masalah Open Ended Ditinjau dari Gaya Kognitif Field Dependent dan Field Independent. MATHEdunesa: Jurnal Ilmiah Pendidikan Matematika, 2(7), 197-204. https://jurnalmahasiswa.unesa.ac.id/index.php/mathedunesa/article/view/25554/23429

Hidayat, B. R., Sugiarto, B., \& Pramesti, G. (2013). Analisis Kesalahan Siswa Dalam Menyelesaikan Soal Pada Materi Ruang Dimensi Tiga Ditinjau Dari Gaya Kognitif Siswa ((Penelitian dilakukan di SMA Negeri 7 Surakarta Kelas X Tahun Ajaran 2011/2012). Jurnal Pendidikan Matematika Solusi, 1(1), 39-46. https://eprints.uns.ac.id/3896/

Hudojo, H. (2005). Pengembangan kurikulum dan pembelajaran matematika. Malang: UM Press. Irdhiyanti, L. (2019). Profil Penalaran Siswa dalam Menyelesaikan Masalah Matematika pada Materi Perbandingan Ditinjau dari Gaya Kognitif Siswa Kelas VII D SMPN 1 Sumbergempol Tulungagung. In Skripsi. IAIN Tulungagung.

Isrokatun, I., Hanifah, N., Maulana, M., \& Suhaebar, I. (2020). Pembelajaran Matematika Dan Sains Secara Integratif Melalui Situation-Based Learning. Sumedang: UPI Sumedang Press.

Khanifah, Sutrisno, \& Purwosetiyono, F. D. (2019). Literasi Matematika Tahap Merumuskan Masalah Secara Matematis Siswa kemampuan Tinggi dalam Memecahkan Masalah Matematika Kelas VIII. JKPM (Jurnal Kajian Pendidikan Matematika), 5(1), 37-48. https://doi.org/http://dx.doi.org/10.30998/jkpm.v5i1.4544

Lastiningsih, N. (2014). Deskripsi Berpikir Siswa SMP Dalam Pengajuan Soal Berdasarkan Taksonomi Empirik Ditinjau Dari Gaya Kognitif Field Independent Dan Field Dependent. Prosiding Seminar Nasinonal Pendidikan Matematika Unnisula, 80.

Miles, M. B., \& Huberman, A. M. (2014). Analisis Data Kualitatif (Buku Sumber Tentang MetodeMetode Baru). Jakarta: UI Press.

Muhtarom, Murtianto, Y. H., \& Sutrisno. (2017). Thinking Process of Students with HighMathematics Ability (A Study on QSR NVivo 11-Assisted Data Analysis). International Journal of Applied Engineering Research, 12(17), 6934-6940.

Mulyatna, F., Nurrahmah, A., \& Seruni. (2020). The Influence of Learning Model and Learning Motivation Towards Mathematical Reasoning Abilities in Junior High School BT - 1st International Conference on Folklore, Language, Education and Exhibition (ICOFLEX 2019). Proceedings of the 1st International Conference on Folklore, Language, Education and Exhibition (ICOFLEX 2019),

295-301. https://doi.org/https://doi.org/10.2991/assehr.k.201230.056

Muslimin, M., \& Sunardi, S. (2019). Analisis Kemampuan Penalaran Matematika Siswa SMA Pada Materi Geometri Ruang. Kreano, Jurnal Matematika Kreatif-Inovatif, 10(2), 171-178. https://doi.org/10.15294/kreano.v10i2.18323

Nasution. (2006). Berbagai Pendekatan dalam Proses Bealajar dan Mengajar. Jakarta: Bumi Aksara. NCTM. (2000). Principles And Standards For School Mathematics. NCTM.

OECD. (2019). PISA 2018 Assessment and Analytical Framework. In OECD Publishing.

Offirstson, T. (2012). Aktivitas Pembelajaran Matematika Melalui Inkuiri Berbantuan Software Cinderella. Yogyakarta: Deepublish.

Putra, A., Murti, B., \& Suriyasa, P. (2013). Hubungan Gaya Kognitif Dan Penalaran Verbal Dengan Prestasi Belajar Mata Kuliah Anatomi II Pada Mahasiswa Pendidikan Jasmani Kesehatan Dan Rekreasi (Fakultas Olahraga Dan Kesehatan Universitas Pendidikan Ganesha). Jurnal Magister Kedokteran Keluarga, 1(1), 92-103. https://eprints.uns.ac.id/2178/1/232-435-1-SM.pdf

QSR International. (2016). NVivo 11 for Windows Help. http://helpnv11.qsrinternational.com/desktop/procedures/run_a_coding_comparison_query.htm\#MiniTO CBookMark2

Raharjo, S., Saleh, H., \& Sawitri, D. (2020). Analisis Kemampuan Penalaran Matematis Siswa Dengan Pendekatan Open-Ended Dalam Pembelajaran Matematika. Paedagoria: Jurnal Kajian, Penelitian Dan Pengembangan Kependidikan, 11(1), 36-43. 
https://doi.org/10.31764/paedagoria.v11i1.1881

Sari, A. P., Sudargo, S., \& Sutrisno, S. (2019). Pengaruh model pembelajaran kooperatif tipe numbered heads together melalui pendekatan PAIKEM terhadap prestasi belajar ditinjau dari gaya kognitif. AKSIOMA : Jurnal Matematika Dan Pendidikan Matematika, 10(1), 48-59. https://doi.org/10.26877/aks.v10i1.3665

Sari, R. H. N. (2015). Literasi Matematika: Apa, Mengapa dan Bagaimana? Prosiding Seminar Nasional Matematika Dan Pendidikan Matematika UNY, 713-720. http://seminar.uny.ac.id/semnasmatematika/sites/seminar.uny.ac.id.semnasmatematika/files/ba nner/PM-102.pdf

Setyaningrum, A., Ariyanto, L., \& Sutrisno, S. (2017). Pengaruh Self-Confidence terhadap Kemampuan Penalaran Matematis Siswa Kelas VII. Seminar Nasional Matematika Dan Pendidikan Matematika (2rd SENATIK), 371-376. http://prosiding.upgris.ac.id/index.php/sen_2017/sen_2017/paper/view/1677

Shadiq, F. (2014). Pemecahan Masalah, Penalaran, dan Komunikasi. Yogyakarta: Widyaswara PPG Matematika.

Somakim, Suharman, A., Kodri, M., \& Taufiq. (2016). Developing Teaching Materials PISA-based for Mathematics and Science of Junior High School. Journal of Education and Prcatice, 7(13), 73-77. https://www.iiste.org/Journals/index.php/JEP/article/view/30623

Sutrisno, S., Mardiyana, M., \& Usodo, B. (2013). Eksperimentasi Model Pembelajaran Kooperatif Tipe STAD dan TPS dengan Pendekatan SAVI terhadap Prestasi dan Motivasi Belajar Ditinjau dari Gaya Belajar Siswa. Jurnal Elektronik Pembelajaran Matematika, 1(7), 661-667. https://jurnal.fkip.uns.ac.id/index.php/s2math/article/view/3538

Sutrisno, Sudargo, \& Titi, R. A. (2019). Analisis Kemampuan Representasi Matematis Siswa SMK Kimia Industri Theresiana Semarang. JIPMat (Jurnal Ilmiah Pendidikan Matematika), 4(1), 6576. https://doi.org/https://doi.org/10.26877/jipmat.v4i1.3626

Utami, T. R. (2020). Analisis Kemampuan Penalaran Matematis Ditinjau dari Gaya Kognitif. In Skripsi. UIN Sunan Gunung Djati.

Yekti, S. M. P., Kusmayadi, T. A., \& Riyadi. (2016). Masalah Aljabar Ditinjau Dari Gaya Kognitif Field Dependent - Field Independent. Journal of Mathematics and Mathematics Education, VI(2), 178-192. https://doi.org/https://doi.org/10.20961/jmme.v6i2.10064 